OPEN ACCESS

Edited by:

Tim I. M. Korevaar,

Erasmus University Rotterdam,

Netherlands

Reviewed by:

Barbara Anne Demeneix,

Centre national de la recherche

scientifique (CNRS), France

Laurent M. Sachs,

Muséum national d'Histoire

naturelle, France

Salvatore Benvenga,

Università degli Studi di

Messina, Italy

${ }^{*}$ Correspondence:

Akhgar Ghassabian

akhgar.ghassabian@nyumc.org

Specialty section: This article was submitted to

Thyroid Endocrinology,

a section of the journal

Frontiers in Endocrinology

Received: 09 February 2018 Accepted: 12 April 2018

Published: 30 April 2018

Citation:

Ghassabian A and Trasande L (2018) Disruption in Thyroid Signaling

Pathway: A Mechanism for the Effect of Endocrine-Disrupting Chemicals on Child Neurodevelopment.

Front. Endocrinol. 9:204. doi: 10.3389/fendo.2018.00204

\section{Disruption in Thyroid Signaling Pathway: A Mechanism for the Effect of Endocrine-Disrupting Chemicals on Child Neurodevelopment}

\author{
Akhgar Ghassabian ${ }^{1,2,3 *}$ and Leonardo Trasande $e^{1,2,3,4,5}$ \\ ${ }^{1}$ Department of Pediatrics, New York University School of Medicine, New York, NY, United States, ${ }^{2}$ Department of \\ Environmental Medicine, New York University School of Medicine, New York, NY, United States, ${ }^{3}$ Department of Population \\ Health, New York University School of Medicine, New York, NY, United States, ${ }^{4}$ NYU Wagner School of Public Service, \\ New York, NY, United States, ${ }^{5}$ NYU College of Global Public Health, New York University, New York, NY, United States
}

Thyroid hormones are crucial in normal brain development. Transient and mild thyroid hormone insufficiency in pregnancy is also associated with impaired neurodevelopment in the offspring (e.g., 3-4 IQ score loss in association with maternal free thyroxine in the lowest fifth percentile). While inadequate iodine intake remains the most common underlying cause of mild thyroid hormone insufficiency in vulnerable populations including pregnant women, other factors such as exposure to environmental contaminants have recently attracted increasing attention, in particular in interaction with iodine deficiency. Endocrine-disrupting chemicals (EDCs) are natural and synthetic substances with ubiquitous exposure in children and adults including pregnant women. EDCs interfere, temporarily or permanently, with hormonal signaling pathways in the endocrine system by binding to hormone receptors and modifying gene expression. Other mechanisms involve alterations in production, metabolism, and transfer of hormones. Experimental studies have shown that exposures to EDCs affect various brain processes such as neurogenesis, neural differentiation and migration, as well as neural connectivity. Neuroimaging studies confirm brain morphological abnormalities (e.g., cortical thinning) consistent with neurodevelopmental impairments as a result of EDC exposures at standard use levels. In this review, we provide an overview of present findings from toxicological and human studies on the anti-thyroid effect of EDCs with a specific attention to fetal and early childhood exposure. This brief overview highlights the need for additional multidisciplinary studies with a focus on thyroid disruption as an underlying mechanism for developmental neurotoxicity of EDC, which can provide insight into modifiable risk factors of developmental delays in children.

Keywords: thyroid, endocrine disrupting chemicals, neurodevelopment, children, brain

Observations of children born with cretinism in iodine deficient areas prompted scientists to discuss the impact of early thyroid function on brain development (1). Decades later, evidence confirmed that undetected or inadequately treated thyroid deficiency in pregnant women was associated with impaired cognition in the offspring, even in the absence of neonatal hypothyroidism (2). A series of influential studies by Morreale de Escobar and colleagues using experimental animal models 
TABLE 1 | Endocrine disrupting chemicals (EDCs) and target of action in the hypothalamus-pituitary-thyroid axis.

\begin{tabular}{|c|c|}
\hline Groups of EDCs & Target of action \\
\hline $\begin{array}{l}\text { Polychlorinated biphenyls and } \\
\text { polychlorinated dibenzodioxins } \\
\text { (PCDD) }\end{array}$ & $\begin{array}{l}\text { Thyroid hormone transportation } \\
\text { Thyroid hormone receptors }\end{array}$ \\
\hline Polybrominated diphenyl ethers & $\begin{array}{l}\text { Thyroid hormone transporters } \\
\text { Deiodinase activity in the thyroid gland } \\
\text { Thyroid hormone receptors } \\
\text { Thyroid hormone metabolism }\end{array}$ \\
\hline Pesticides & $\begin{array}{l}\text { Histology of thyroid gland } \\
\text { Thyroid hormone transportation } \\
\text { Thyroid hormone receptors }\end{array}$ \\
\hline $\begin{array}{l}\text { Perfluoroalkyl substances } \\
\text { (PFASs) }\end{array}$ & $\begin{array}{l}\text { Thyroid hormone transportation } \\
\text { Deiodinase activity in the thyroid gland }\end{array}$ \\
\hline Sodium iodide symporters (NIS) & lodine uptake into the thyroid gland \\
\hline Bisphenol A and other phenols & $\begin{array}{l}\text { Expression of thyroid receptor genes } \\
\text { in the pituitary } \\
\text { Thyroid hormone receptors }\end{array}$ \\
\hline Phthalates & $\begin{array}{l}\text { Thyroid-releasing hormone receptor } \\
\text { in the hypothalamus and pituitary } \\
\text { Thyroid-stimulating hormone receptor } \\
\text { in the thyroid gland } \\
\text { Expression of genes related to thyroid hormone } \\
\text { metabolism, synthesis, and transportation }\end{array}$ \\
\hline
\end{tabular}

identified structural and functional abnormalities in the cerebral cortex and the hippocampus due to low thyroid hormones during gestation (3-5). Recently, epidemiological studies confirmed that transient as well as mild thyroid hormone insufficiency during critical windows of brain development were also associated with impaired cognition, psychomotor and language development, behavioral problems, and abnormal cortical and subcortical morphology (6-12).

While inadequate iodine intake remains the most common cause of thyroid insufficiency worldwide (13), other factors including autoimmunity (14) and environmental chemicals in routine doses of exposure have recently attracted increasing attention $(15,16)$. Several experimental studies have shown that exposure to endocrine-disrupting chemicals (EDCs) affects neural differentiation and migration and neural connectivity (17). Growing evidence on adverse health effects of certain EDCs, such as polychlorinated biphenyls (PCBs) and polybrominated diphenyl ethers (PBDEs), has led to stringent policies to control exposure. EDCs interfere with thyroid function at different levels including the central regulatory system in the hypothalamus and pituitary, thyroid hormone production at the thyroid gland, thyroid hormone transfer, as well as hormone bioavailability, function, and metabolism (16) (Figure 1, Table 1). Many EDCs pass through the placenta and blood-brain barrier and are also secreted in breastmilk $(18,19)$. Since circulation of thyroid hormones in the cerebral spinal fluid (CSF) resembles of the levels in the serum, EDCs potentially interfere with thyroid hormone carriers in the CSF when cross the blood brain barrier. Here, we briefly review seven groups of substances with anti-thyroid activities.

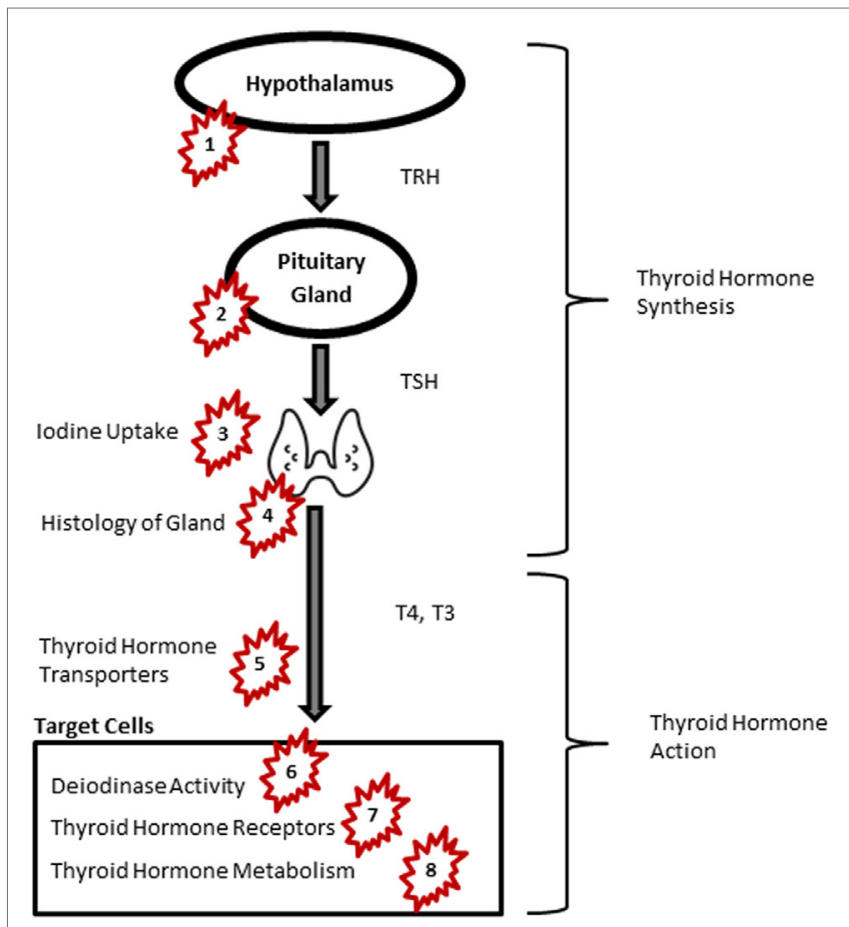

FIGURE 1 | Thyroid signaling pathway and endocrine-disrupting chemicals. Groups of chemicals act at: PCB and PCDD: 5, 7; PBDEs: 5, 6, 7, 8; pesticides: 4, 5, 7; PFASs: 5, 6; NIS: 3; BPA: 2, 7; phthalates: 1, 2, 5, 8. Abbreviations: BPA, bisphenol A; NIS, sodium iodide symporters; PBDE, polybrominated diphenyl ethers; PCB, polychlorinated biphenyl; PCDD, polychlorinated dibenzodioxins; PFAS, perfluoroalkyl substances; TRH, thyroid-releasing hormone; TSH, thyroid-stimulating hormone; T4, thyroxine; T3, triiodothyronine. Image of thyroid: by P. J. Witt, AU from the Noun Project, Creative Commons.

\section{PCB AND POLYCHLORINATED DIBENZODIOXINS (PCDD)}

Polychlorinated biphenyls and polychlorinated dibenzodioxins (PCDD) are persistent organic pollutants, which are no longer produced due to their carcinogenic effects (20), but are present in several products manufactured prior to banning (21). PCBs and their metabolites bind to thyroid transport proteins such as transthyretin and interfere with thyroid hormone transport (22). The action of PCBs at the level of thyroid receptor (TR) activity is both agonistic and antagonistic, depending on PCB congeners and the target tissue. Specific PCB metabolites, if hydroxylated by the metabolic enzyme cytochrome P450 1A1, act as TR agonists and impact mRNA expression of well-known thyroid hormone-response genes in the liver and in the pituitary (23). PCBs can also bind to TR and antagonize triiodothyronine (T3) inhibiting TR-mediated gene activation. Experimental studies in rats have shown that thyroid regulated events during early development, e.g., neuronal migration in the cortex, are disturbed with PCB exposure (24). PCBs, in concentrations commonly observed in humans, interfere with thyroid hormone receptor signaling (mainly through TR $\beta$ complex) and disturb oligodendrocyte differentiation and white matter maturation during early development (25). 
Substantial evidence from epidemiological studies has shown associations between PCB or PCDD exposures and abnormal thyroid parameters. Cross-sectional examination of serum PCB and dioxin levels and thyroid parameters have shown positive associations between serum thyroid-stimulating hormone (TSH) and PCB congeners and PCDD and negative associations between PCBs and T3 and thyroxine (T4), with stronger associations among women (26-29). In cord blood, there is an inverse association between concentrations of organochlorine compounds and free T3 (fT3) and free T4 (fT4), but not TSH (30). Similar associations are shown in longitudinal studies $(31,32)$. Positive associations between serum PCB and T3 and T4 (33-35) and null associations between serum PCB and thyroid parameters are also reported (36). Methodological considerations (e.g., standardizing methods) might explain the differences in the observed associations (37). Overall, human studies support findings from animal models and show that concentrations of PCB and PCDD at levels commonly detected in the general population can interfere with thyroid function. Further studies are still needed, however, to assess whether the observed effects of PCBs on early brain development $(38,39)$ are partly (thyroid disruption together with direct neurotoxicity or other mechanism) or fully (entirely through disruption in thyroid signaling pathway) explained by their thyroid disrupting activities.

\section{POLYBROMINATED DIPHENYL ETHERS}

Polybrominated diphenyl ethers are organic compounds that are used as flame retardants in building materials, electronics, furnishing, and textiles. The usage of some PBDE congeners is increasingly being controlled; however, due to their high resistance to degradation processes, people are still exposed to PBDEs. PBDEs have a similar chemical structure to thyroid hormones. Experimental studies have shown that PBDEs, at environmentally relevant doses, bind to receptors, and inhibit binding of T3 to TRs, and suppress T3 actions $(40,41)$. Other mechanisms of actions are a competitive binding for serum transporters (e.g., transthyretin and thyroid binding globulin), upregulation of clearance enzymes (e.g., glucuronidases) and liver metabolism, and inhibition of thyroid deiodinase activity $(42,43)$. In zebrafish, decabromodiphenyl ether (BDE-209) exposure in parents induces a decrease in $\mathrm{T} 4$ and a downregulation in expression of TR genes (44). Similar inverse associations between exposure to $\mathrm{PBDE}$ congeners and thyroid hormones have been reported in other studies (45-47). While human studies confirm thyroid disruption by PBDEs, the direction of this association varies across studies and PBDE congeners. For example, BDE-153 levels have been inversely associated with first trimester total T3 (29) and TSH in pregnant women [but not with fT4 and total T4 (TT4)] (48). Another longitudinal study has shown positive correlations between maternal BDE-47, BDE-99, and BDE-100 during pregnancy and T3 in cord blood (39). Both higher and lower levels of $\mathrm{T} 3$ have been reported in association with PBDE exposure in pregnant women $(49,50)$. A decrease in cord blood fT4 and maternal TT4 and fT3 at delivery are shown in relation to maternal PBDE exposure in early pregnancy (51). Considering that several epidemiological studies have shown the impact of prenatal PBDE exposure on neuropsychological, motor, and cognitive functioning in children $(39,52,53)$, thyroid disruptive properties of PBDE congeners can be one of the underlying mechanisms for the adverse effect on early brain development.

\section{PESTICIDES}

Individuals are widely exposed to pesticides. Several pesticides are currently banned; however, they are still detectible in the environment from previous use (54). Chlorpyrifos, the top selling pesticide in the United States (US) have been increasingly used for corn production despite stringent regulations for domestic use (55). Toxicological evidence has shown long-term disruption of thyroid function by these chemicals (56-58) and human studies have confirmed the association $(59,60)$. The potential actions on the thyroid system are the perturbation of thyroid hormone transport as well as histological and histomorphometrical effects on the thyroid gland $(58,61)$. There is strong epidemiological evidence that show the effect of prenatal exposure to chlorpyrifos and other pesticides on neurodevelopment, including childhood tremor, delayed psychomotor and mental development, IQ loss, and ASD (62-65). A neuroimaging study in 40 six- to eleven-yearold children has found that higher neonatal levels of chlorpyrifos are associated with several brain morphological abnormalities including cortical thinning and abnormal morphological measures of cerebral surface, consistent with neurocognitive findings (66). Mechanistic studies and comparison of chlorpyrifos exposure neuroimaging findings with brain influences of thyroid disruption will further unravel the mechanism for the neurotoxicity of chlorpyrifos and other pesticides.

\section{PERFLUOROALKYL SUBSTANCES (PFASs)}

Perfluoroalkyl substances are persistent chemicals which are widely used in textiles, furniture, and cookware $(67,68)$. Since 2002, major US companies have been phasing out two PFASs, perfluorooctanoic acid (PFOA), and perfluorooctane sulfonate (PFOS). Nonetheless, PFOS and PFOA were detectible in children from the National Health and Nutrition Examination Survey (NHANES) 2013-2014 (69) suggesting that children born after voluntarily discontinuation have been exposed to PFASs. PFASs interfere with bindings of thyroid hormone to transthyretin (70) and upregulate deiodinase in the thyroid gland (71). Serum PFOS and PFNA have been associated with an increase in TT4 (72). Cord blood perfluoro $n$-pentanoic acid has been positively associated with cord blood TT4 (73). In a sample of newborns, girls in the highest quartile of PFOA exposure during prenatal period showed increased T4 levels compared to the lowest quartile (74). In another study, cord blood concentration of perfluoro $n$-pentanoic acid and perfluorohexane sulfonic acid was associated with increased T4 and T3 levels (in the cord blood), while PFNA was associated with decreased TSH concentration in newborn girls (73). Inconsistent results have been reported regarding the effect of PFASs on child neurodevelopment such as cognition, behaviors and executive function, developmental milestones, psychomotor 
development, and academic achievement (75). While some studies showing no association between maternal serum PFOA and PFOS in early pregnancy and child neurodevelopment (76-79), others found positive associations (80-83). Quaak et al. reported a sex-specific effect (84). Thyroid disruption together with influences on other parts of the endocrine system might explain these sex-specific effects $(85,86)$.

\section{SODIUM IODIDE SYMPORTERS (NIS)}

Perchlorate, thiocyanate, and nitrate competitively inhibit the NIS - a transmembrane protein responsible for iodide uptake into the thyroid gland at the membrane of thyroid follicular cells. They interfere with thyroid iodine uptake, and affect thyroid hormone production and bioavailability (87). Individuals are exposed to these contaminants through food or other sources (e.g., cigarette smoke for thiocyanate or rocket propellant and fertilizers for perchlorate and nitrate). Though these chemicals do arise naturally, anthropogenic activities are a major source of exposure. In the 2001-2002 NHANES data, there was an inverse association between urinary levels of perchlorate and TT4 and a positive association with TSH (88). A similar positive association has been reported between urinary perchlorate, nitrate, and thiocyanate and fT4, with indications for a sex-specific effect (89). Adolescent boys and girls are vulnerable subpopulations to thyroid-blocking effects of NIS inhibitors (90). In the Controlled Antenatal Thyroid Screening Study, maternal perchlorate in the first trimester of pregnancy have been associated with reduced IQ in the children of hypothyroid or hypothyroxinemic pregnant women, suggesting that high exposures during sensitive windows of brain development in combination with maternal thyroid status might adversely influence neurodevelopment (91).

\section{BISPHENOL A (BPA) AND OTHER PHENOLS}

Bisphenols are organic synthetic compounds widely used in the production of aluminum cans, plastics, thermal paper receipts, and food packaging. Bisphenol A is detectible in $>90 \%$ of urine samples in the US population (92). BPA is a weak estrogenic substance (93) but also interferes with thyroid function $(94,95)$. In vivo, BPA can impair thyroid hormone action by antagonizing $\mathrm{T}_{3}$-induced TR activation (TR $\alpha 1$ and TR $\left.\beta 1\right)$ and by suppressing its transcriptional activity in a dose-dependent manner (94). Another study suggests that BPA acts selectively as TR antagonists on TR $\beta$-independent of its estrogenic effects-causing serum $\mathrm{T}_{4}$ to rise (95). Prenatal exposure to BPA in rats is shown to upregulate $\mathrm{TR} \alpha \mathrm{mRNA}$ expression in the fetal forebrain and alters neuronal migration patterns during corticogenesis (96). BPA and its structural analogs cause dysregulation of TR gene expression in pituitary cells and thyroid gland (97). Triclosan affects thyroid hormone-dependent metamorphosis in animals (98).

Cross-sectional studies have shown that higher urinary levels of BPA are associated with lower fT4 and TSH (99-102). In a cohort of pregnant women, modest associations have been reported between higher BPA and lower TT4, if measurements were close in time (103). In follow-up studies, negative correlations have been shown between maternal BPA and TSH in newborns (104). In boys, an inverse association has been shown between maternal BPA in the third trimester and serum TSH (103). The latter is in line with findings of epidemiological studies that have shown the sex-specific association between prenatal BPA and child behavior (105-110). In sum, BPA dysregulates thyroid function leading to a positive association with $\mathrm{T} 3$ and an inverse association with T4 and TSH. Estrogenic effects or other sex hormone disruption mechanisms of BPA exposure on the offspring's thyroid parameters might explain differential effects observed on behavioral outcomes of boys and girls.

\section{PHTHALATES}

People are ubiquitously exposed to phthalates, non-persistent synthetic chemicals that are used in plastic and consumer products such as cosmetics, adhesives, and detergents. Some forms of phthalates such as di-2-ethylhexylphthalate (DEHP) are no longer used in baby toys; yet phthalates metabolites remain detectible in individuals across age groups $(111,112)$. Urinary phthalates are cross-sectionally associated with lower fT4 and higher TSH (99, 113, 114). One study has found an inverse association between non-DEHP and fT4 in girls only (113) and another study has reported inverse associations between DEHP concentrations and fT4 in girls (115). In the later, urinary concentrations of dibutyl phthalate have been inversely associated with fT3 in boys (115). Higher concentrations of phthalates in maternal prenatal urine samples have been associated with lower thyroid hormones (116). Longitudinal studies in pregnant women have also found that phthalate metabolites are inversely associated with TSH $(117,118)$ and positively associated with fT4 and TT4 (118). Null associations between prenatal DEHP exposure and infant thyroid hormones have also been reported (119).

Despite data suggesting thyroid dysregulation resulting from phthalate exposure, specific underlying mechanisms are poorly understood. A recent experimental study in rats has shown that DEHP can downregulate the thyroid-releasing hormone (TRH) receptor in the hypothalamus, upregulate the protein and $\mathrm{mRNA}$ levels of TRH receptor in the pituitary, and downregulate mRNA expression of TSH receptors in the thyroid (120). In zebra fish larvae, phthalate exposure alters the transcription of genes in the hypothalamic-pituitary-thyroid axis resulting in an increased T3 and decreased T4 (121). To confirm the extent to which these findings from animal models translate into humans further studies are needed. Considering the potential link between phthalates and impaired neurodevelopment (122-125), future studies should focus on thyroid dysfunction as a mediating factor.

Concern is growing regarding the long-lasting effect of chemicals, routinely found in the environment, on the fetal and child brain through anti-thyroid capacities. Thyroid disruption is of particular interest because several EDCs interfere with thyroid function in a sex-specific manner, which might explain the sexual dimorphism in the brain effect of EDCs. EDCs comprise of various compounds with different mechanisms of anti-thyroid effects. This might explain a heterogeneous neurodevelopmental outcomes associated with EDCs. Thyroid disruptive effects of chemicals in combination with or independent of iodine 
deficiency is another topic which has been sparsely considered in epidemiological settings.

Additional multidisciplinary studies with a focus on thyroid disruption as an underlying mechanism can strengthen the existing knowledge on the neurotoxicity EDC. Two such interdisciplinary efforts have been started in Europe and in the US. The LifeCycle Project is a European network of population-based birth cohorts which aims to examine the impact of early life stressors on health and development using a life course approach. In the US, the Environmental Influences on Child Health Outcomes (ECHO) program uses information from 50,000 children and their families from across the US "to enhance the health of children for generations to come" (126). This information comprises several key elements including demographics, environmental exposures, biological measures, and child health outcomes. $\mathrm{ECHO}$, the LifeCycle Project and similar efforts can be used as a

\section{REFERENCES}

1. McCarrison R. The Thyroid Gland in Health and Disease. London: Baillière, Tindall and Cox (1917).

2. Haddow JE, Palomaki GE, Allan WC, Williams JR, Knight GJ, Gagnon J, et al. Maternal thyroid deficiency during pregnancy and subsequent neuropsychological development of the child. N Engl J Med (1999) 341(8):549-55. doi:10.1056/NEJM199908193410801

3. Lavado-Autric R, Auso E, Garcia-Velasco JV, Arufe Mdel C, Escobar del Rey F, Berbel P, et al. Early maternal hypothyroxinemia alters histogenesis and cerebral cortex cytoarchitecture of the progeny. J Clin Invest (2003) 111(7):1073-82. doi:10.1172/JCI200316262

4. Morreale de Escobar G, Obregon MJ, Escobar del Rey F. Role of thyroid hormone during early brain development. Eur J Endocrinol (2004) 151(Suppl 3): U25-37. doi:10.1530/eje.0.151U025

5. Berbel P, Navarro D, Auso E, Varea E, Rodriguez AE, Ballesta JJ, et al. Role of late maternal thyroid hormones in cerebral cortex development: an experimental model for human prematurity. Cereb Cortex (2010) 20(6):1462-75. doi:10.1093/cercor/bhp212

6. Ghassabian A, El Marroun H, Peeters RP, Jaddoe VW, Hofman A, Verhulst FC, et al. Downstream effects of maternal hypothyroxinemia in early pregnancy: nonverbal IQ and brain morphology in school-age children. J Clin Endocrinol Metab (2014) 99(7):2383-90. doi:10.1210/jc.2013-4281

7. Roman GC, Ghassabian A, Bongers-Schokking JJ, Jaddoe VW, Hofman A, de Rijke YB, et al. Association of gestational maternal hypothyroxinemia and increased autism risk. Ann Neurol (2013) 74(5):733-42. doi:10.1002/ ana.23976

8. Päkkilä F, Männistö T, Pouta A, Hartikainen A-L, Ruokonen A, Surcel H-M, et al. The impact of gestational thyroid hormone concentrations on ADHD symptoms of the child. J Clin Endocrinol Metab (2014) 99(1):E1-8. doi:10.1210/ jc. 2013-2943

9. Clairman H, Skocic J, Lischinsky JE, Rovet J. Do children with congenital hypothyroidism exhibit abnormal cortical morphology? Pediatr Res (2015) 78(3):286-97. doi:10.1038/pr.2015.93

10. Modesto T, Tiemeier H, Peeters RP, Jaddoe VW, Hofman A, Verhulst FC, et al. Maternal mild thyroid hormone insufficiency in early pregnancy and attention-deficit/hyperactivity disorder symptoms in children. JAMA Pediatr (2015) 169(9):838-45. doi:10.1001/jamapediatrics.2015.0498

11. Samadi A, Skocic J, Rovet JF. Children born to women treated for hypothyroidism during pregnancy show abnormal corpus callosum development. Thyroid (2015) 25(5):494-502. doi:10.1089/thy.2014.0548

12. Lischinsky JE, Skocic J, Clairman H, Rovet J. Preliminary findings show maternal hypothyroidism may contribute to abnormal cortical morphology in offspring. Front Endocrinol (2016) 7:16. doi:10.3389/fendo.2016.00016

13. Zimmermann MB, Boelaert K. Iodine deficiency and thyroid disorders. Lancet Diabetes Endocrinol (2015) 3(4):286-95. doi:10.1016/S2213-8587(14) 70225-6

14. Stagnaro-Green A, Abalovich M, Alexander E, Azizi F, Mestman J, Negro R, et al. Guidelines of the American Thyroid Association for the diagnosis and valuable platform for mechanistic studies of EDC exposure and child neurodevelopment, which subsequently provide insight into modifiable risk factors of developmental delays in children. Such research will further clarify the unfavorable effects of EDCs in the context of dietary factors and other health conditions such as autoimmunity $(127,128)$.

\section{AUTHOR CONTRIBUTIONS}

AG and LT drafted the manuscript and reviewed the final draft for submission.

\section{FUNDING}

LT is supported by National Institutes of Health grant UG3OD023305.

management of thyroid disease during pregnancy and postpartum. Thyroid (2011) 21(10):1081-125. doi:10.1089/thy.2011.0087

15. Zoeller RT, Brown TR, Doan LL, Gore AC, Skakkebaek NE, Soto AM, et al. Endocrine-disrupting chemicals and public health protection: a statement of principles from The Endocrine Society. Endocrinology (2012) 153(9): 4097-110. doi:10.1210/en.2012-1422

16. Preau L, Fini JB, Morvan-Dubois G, Demeneix B. Thyroid hormone signaling during early neurogenesis and its significance as a vulnerable window for endocrine disruption. Biochim Biophys Acta (2015) 1849(2):112-21. doi:10.1016/j.bbagrm.2014.06.015

17. Somogyi V, Horvath TL, Toth I, Bartha T, Frenyo LV, Kiss DS, et al. Bisphenol A influences oestrogen- and thyroid hormone-regulated thyroid hormone receptor expression in rat cerebellar cell culture. Acta Vet Hung (2016) 64(4) 497-513. doi:10.1556/004.2016.046

18. Ikezuki Y, Tsutsumi O, Takai Y, Kamei Y, Taketani Y. Determination of bisphenol A concentrations in human biological fluids reveals significant early prenatal exposure. Hum Reprod (2002) 17(11):2839-41. doi:10.1093/ humrep/17.11.2839

19. Mose T, Knudsen LE, Hedegaard M, Mortensen GK. Transplacental transfer of monomethyl phthalate and mono(2-ethylhexyl) phthalate in a human placenta perfusion system. Int J Toxicol (2007) 26(3):221-9. doi:10.1080/ 10915810701352721

20. Lauby-Secretan B, Loomis D, Grosse Y, El Ghissassi F, Bouvard V, Benbrahim-Tallaa L, et al. Carcinogenicity of polychlorinated biphenyls and polybrominated biphenyls. Lancet Oncol (2013) 14(4):287-8. doi:10.1016/ S1470-2045(13)70104-9

21. Xue J, Liu SV, Zartarian VG, Geller AM, Schultz BD. Analysis of NHANES measured blood PCBs in the general US population and application of SHEDS model to identify key exposure factors. J Expo Sci Environ Epidemiol (2014) 24(6):615-21. doi:10.1038/jes.2013.91

22. Duntas LH, Stathatos N. Toxic chemicals and thyroid function: hard facts and lateral thinking. Rev Endocr Metab Disord (2015) 16(4):311-8. doi:10.1007/ s11154-016-9331-x

23. Giera S, Bansal R, Ortiz-Toro TM, Taub DG, Zoeller RT. Individual polychlorinated biphenyl (PCB) congeners produce tissue- and gene-specific effects on thyroid hormone signaling during development. Endocrinology (2011) 152(7):2909-19. doi:10.1210/en.2010-1490

24. Naveau E, Pinson A, Gerard A, Nguyen L, Charlier C, Thome JP, et al. Alteration of rat fetal cerebral cortex development after prenatal exposure to polychlorinated biphenyls. PLoS One (2014) 9(3):e91903. doi:10.1371/ journal.pone.0091903

25. Fritsche E, Cline JE, Nguyen N-H, Scanlan TS, Abel J. Polychlorinated Biphenyls disturb differentiation of normal human neural progenitor cells: clue for involvement of thyroid hormone receptors. Environ Health Perspect (2005) 113(7):871-6. doi:10.1289/ehp.7793

26. Hagmar L, Rylander L, Dyremark E, Klasson-Wehler E, Erfurth EM. Plasma concentrations of persistent organochlorines in relation to thyrotropin and thyroid hormone levels in women. Int Arch Occup Environ Health (2001) 74(3):184-8. doi:10.1007/s004200000213 
27. Turyk ME, Anderson HA, Persky VW. Relationships of thyroid hormones with polychlorinated biphenyls, dioxins, furans, and DDE in adults. Environ Health Perspect (2007) 115(8):1197-203. doi:10.1289/ehp.10179

28. Abdelouahab N, Mergler D, Takser L, Vanier C, St-Jean M, Baldwin M, et al. Gender differences in the effects of organochlorines, mercury, and lead on thyroid hormone levels in lakeside communities of Quebec (Canada). Environ Res (2008) 107(3):380-92. doi:10.1016/j.envres.2008.01.006

29. Lignell S, Aune M, Darnerud PO, Stridsberg M, Hanberg A, Larsson SC, et al. Maternal body burdens of PCDD/Fs and PBDEs are associated with maternal serum levels of thyroid hormones in early pregnancy: a cross-sectional study. Environ Health (2016) 15:55. doi:10.1186/s12940-016-0139-7

30. Maervoet J, Vermeir G, Covaci A, Van Larebeke N, Koppen G, Schoeters G, et al. Association of thyroid hormone concentrations with levels of organochlorine compounds in cord blood of neonates. Environ Health Perspect (2007) 115(12):1780-6. doi:10.1289/ehp.10486

31. Darnerud PO, Lignell S, Glynn A, Aune M, Tornkvist A, Stridsberg M. POP levels in breast milk and maternal serum and thyroid hormone levels in mother-child pairs from Uppsala, Sweden. Environ Int (2010) 36(2):180-7. doi:10.1016/j.envint.2009.11.001

32. Gaum PM, Lang J, Esser A, Schettgen T, Neulen J, Kraus T, et al. Exposure to polychlorinated biphenyls and the thyroid gland - examining and discussing possible longitudinal health effects in humans. Environ Res (2016) 148:112-21. doi:10.1016/j.envres.2016.03.022

33. Su PH, Chen JY, Chen JW, Wang SL. Growth and thyroid function in children with in utero exposure to dioxin: a 5-year follow-up study. Pediatr Res (2010) 67(2):205-10. doi:10.1203/PDR.0b013e3181c8f04b

34. Su PH, Chen HY, Chen SJ, Chen JY, Liou SH, Wang SL. Thyroid and growth hormone concentrations in 8-year-old children exposed in utero to dioxins and polychlorinated biphenyls. J Toxicol Sci (2015) 40(3):309-19. doi:10.2131/jts.40.309

35. Jacobson MH, Darrow LA, Barr DB, Howards PP, Lyles RH, Terrell ML, et al. Serum polybrominated biphenyls (PBBs) and polychlorinated biphenyls (PCBs) and thyroid function among Michigan adults several decades after the 1973-1974 PBB contamination of livestock feed. Environ Health Perspect (2017) 125(9):097020. doi:10.1289/EHP1302

36. Wilhelm M, Wittsiepe J, Lemm F, Ranft U, Kramer U, Furst P, et al. The Duisburg birth cohort study: influence of the prenatal exposure to PCDD/Fs and dioxin-like PCBs on thyroid hormone status in newborns and neurodevelopment of infants until the age of 24 months. Mutat Res (2008) 659(1-2):83-92. doi:10.1016/j.mrrev.2007.11.002

37. Schisterman EF, Whitcomb BW, Louis GM, Louis TA. Lipid adjustment in the analysis of environmental contaminants and human health risks. Environ Health Perspect (2005) 113(7):853-7. doi:10.1289/ehp.7640

38. Park HY, Park JS, Sovcikova E, Kocan A, Linderholm L, Bergman A, et al. Exposure to hydroxylated polychlorinated biphenyls (OH-PCBs) in the prenatal period and subsequent neurodevelopment in eastern Slovakia. Environ Health Perspect (2009) 117(10):1600-6. doi:10.1289/ehp.0900611

39. Roze E, Meijer L, Bakker A, Van Braeckel KN, Sauer PJ, Bos AF. Prenatal exposure to organohalogens, including brominated flame retardants, influences motor, cognitive, and behavioral performance at school age. Environ Health Perspect (2009) 117(12):1953-8. doi:10.1289/ehp.0901015

40. Kitamura S, Kato T, Iida M, Jinno N, Suzuki T, Ohta S, et al. Anti-thyroid hormonal activity of tetrabromobisphenol A, a flame retardant, and related compounds: affinity to the mammalian thyroid hormone receptor, and effect on tadpole metamorphosis. Life Sci (2005) 76(14):1589-601. doi:10.1016/j.lfs. 2004.08.030

41. Fini J-B, Le Mével S, Turque N, Palmier K, Zalko D, Cravedi J-P, et al. An in vivo multiwell-based fluorescent screen for monitoring vertebrate thyroid hormone disruption. Environ Sci Technol (2007) 41(16):5908-14. doi:10.1021/es0704129

42. Szabo DT, Richardson VM, Ross DG, Diliberto JJ, Kodavanti PR, Birnbaum LS. Effects of perinatal PBDE exposure on hepatic phase I, phase II, phase III, and deiodinase 1 gene expression involved in thyroid hormone metabolism in male rat pups. Toxicol Sci (2009) 107(1):27-39. doi:10.1093/toxsci/kfn230

43. Hoffman K, Sosa JA, Stapleton HM. Do flame retardant chemicals increase the risk for thyroid dysregulation and cancer? Curr Opin Oncol (2017) 29(1):7-13. doi:10.1097/CCO.0000000000000335

44. Han Z, Li Y, Zhang S, Song N, Xu H, Dang Y, et al. Prenatal transfer of decabromodiphenyl ether (BDE-209) results in disruption of the thyroid system and developmental toxicity in zebrafish offspring. Aquat Toxicol (2017) 190:46-52. doi:10.1016/j.aquatox.2017.06.020

45. Zhou T, Ross DG, DeVito MJ, Crofton KM. Effects of short-term in vivo exposure to polybrominated diphenyl ethers on thyroid hormones and hepatic enzyme activities in weanling rats. Toxicol Sci (2001) 61(1):76-82. doi:10.1093/toxsci/61.1.76

46. Lee E, Kim TH, Choi JS, Nabanata P, Kim NY, Ahn MY, et al. Evaluation of liver and thyroid toxicity in Sprague-Dawley rats after exposure to polybrominated diphenyl ether BDE-209. J Toxicol Sci (2010) 35(4):535-45. doi: $10.2131 /$ jts.35.535

47. Marteinson SC, Palace V, Letcher RJ, Fernie KJ. Disruption of thyroxine and sex hormones by 1,2-dibromo-4-(1,2-dibromoethyl)cyclohexane (DBE-DBCH) in American kestrels (Falco sparverius) and associations with reproductive and behavioral changes. Environ Res (2017) 154:389-97. doi:10.1016/j. envres.2017.01.005

48. Chevrier J, Harley KG, Bradman A, Gharbi M, Sjödin A, Eskenazi B. Polybrominated diphenyl ether (PBDE) flame retardants and thyroid hormone during pregnancy. Environ Health Perspect (2010) 118(10):1444-9. doi:10.1289/ehp.1001905

49. Stapleton HM, Eagle S, Anthopolos R, Wolkin A, Miranda ML. Associations between polybrominated diphenyl ether (PBDE) flame retardants, phenolic metabolites, and thyroid hormones during pregnancy. Environ Health Perspect (2011) 119(10):1454-9. doi:10.1289/ehp.1003235

50. Zota AR, Park JS, Wang Y, Petreas M, Zoeller RT, Woodruff TJ. Polybrominated diphenyl ethers, hydroxylated polybrominated diphenyl ethers, and measures of thyroid function in second trimester pregnant women in California. Environ Sci Technol (2011) 45(18):7896-905. doi:10.1021/es200422b

51. Abdelouahab N, Langlois M-F, Lavoie L, Corbin F, Pasquier J-C, Takser L. Maternal and cord-blood thyroid hormone levels and exposure to polybrominated diphenyl ethers and polychlorinated biphenyls during early pregnancy. Am J Epidemiol (2013) 178(5):701-13. doi:10.1093/aje/ kwt141

52. Herbstman JB, Sjödin A, Kurzon M, Lederman SA, Jones RS, Rauh V, et al. Prenatal exposure to PBDEs and neurodevelopment. Environ Health Perspect (2010) 118(5):712-9. doi:10.1289/ehp.0901340

53. Chen A, Yolton K, Rauch SA, Webster GM, Hornung R, Sjodin A, et al. Prenatal polybrominated diphenyl ether exposures and neurodevelopment in U.S. children through 5 years of age: the HOME study. Environ Health Perspect (2014) 122(8):856-62. doi:10.1289/ehp.1307562

54. Fry K, Power MC. Persistent organic pollutants and mortality in the United States, NHANES 1999-2011. Environ Health (2017) 16(1):105. doi:10.1186/ s12940-017-0313-6

55. Trasande L. When enough data are not enough to enact policy: the failure to ban chlorpyrifos. PLoS Biol (2017) 15(12):e2003671. doi:10.1371/journal. pbio. 2003671

56. Satar S, Satar D, Kirim S, Leventerler H. Effects of acute organophosphate poisoning on thyroid hormones in rats. Am J Ther (2005) 12(3):238-42. doi:10.1016/j.toxlet.2006.07.169

57. Jeong SH, Kim BY, Kang HG, Ku HO, Cho JH. Effect of chlorpyrifos-methyl on steroid and thyroid hormones in rat F0- and F1-generations. Toxicology (2006) 220(2-3):189-202. doi:10.1016/j.tox.2006.01.005

58. De Angelis S, Tassinari R, Maranghi F, Eusepi A, Di Virgilio A, Chiarotti F, et al. Developmental exposure to chlorpyrifos induces alterations in thyroid and thyroid hormone levels without other toxicity signs in Cd1 Mice. Toxicol Sci (2009) 108(2):311-9. doi:10.1093/toxsci/kfp017

59. Luo D, Pu Y, Tian H, Wu W, Sun X, Zhou T, et al. Association of in utero exposure to organochlorine pesticides with thyroid hormone levels in cord blood of newborns. Environ Pollut (2017) 231(Pt 1):78-86. doi:10.1016/j. envpol.2017.07.091

60. Wang Y, Chen L, Wang C, Hum Y, Gao Y, Zhou Y, et al. Association between organophosphate pesticide exposure and thyroid hormones in pregnant women. Epidemiology (2017) 28(Suppl 1):S35-40. doi:10.1097/ EDE.0000000000000721

61. Hill KL, Hamers T, Kamstra JH, Willmore WG, Letcher RJ. Organophosphate triesters and selected metabolites enhance binding of thyroxine to human transthyretin in vitro. Toxicol Lett (2018) 285:87-93. doi:10.1016/j.toxlet. 2017.12.030

62. Perera FP, Rauh V, Tsai WY, Kinney P, Camann D, Barr D, et al. Effects of transplacental exposure to environmental pollutants on birth outcomes in 
a multiethnic population. Environ Health Perspect (2003) 111(2):201-5. doi:10.1289/ehp. 5742

63. Rauh VA, Garfinkel R, Perera FP, Andrews HF, Hoepner L, Barr DB, et al. Impact of prenatal chlorpyrifos exposure on neurodevelopment in the first 3 years of life among inner-city children. Pediatrics (2006) 118(6):e1845-59. doi:10.1542/peds.2006-0338

64. Shelton JF, Geraghty EM, Tancredi DJ, Delwiche LD, Schmidt RJ, Ritz B, et al. Neurodevelopmental disorders and prenatal residential proximity to agricultural pesticides: the CHARGE study. Environ Health Perspect (2014) 122(10):1103-9. doi:10.1289/ehp.1307044

65. Rauh VA, Garcia WE, Whyatt RM, Horton MK, Barr DB, Louis ED. Prenatal exposure to the organophosphate pesticide chlorpyrifos and childhood tremor. Neurotoxicology (2015) 51:80-6. doi:10.1016/j.neuro.2015.09.004

66. Rauh VA, Perera FP, Horton MK, Whyatt RM, Bansal R, Hao X, et al. Brain anomalies in children exposed prenatally to a common organophosphate pesticide. Proc Natl Acad Sci U S A (2012) 109(20):7871-6. doi:10.1073/ pnas. 1203396109

67. Olsen GW, Burris JM, Ehresman DJ, Froehlich JW, Seacat AM, Butenhoff JL, et al. Half-life of serum elimination of perfluorooctanesulfonate, perfluorohexanesulfonate, and perfluorooctanoate in retired fluorochemical production workers. Environ Health Perspect (2007) 115(9):1298-305. doi:10.1289/ ehp. 10009

68. Lindstrom AB, Strynar MJ, Libelo EL. Polyfluorinated compounds: past, present, and future. Environ Sci Technol (2011) 45(19):7954-61. doi:10.1021/ es2011622

69. Ye X, Kato K, Wong LY, Jia T, Kalathil A, Latremouille J, et al. Per- and polyfluoroalkyl substances in sera from children 3 to 11 years of age participating in the National Health and Nutrition Examination Survey 2013-2014. Int J Hyg Environ Health (2018) 221(1):9-16. doi:10.1016/j.ijheh.2017.09.011

70. Weiss JM, Andersson PL, Lamoree MH, Leonards PE, van Leeuwen SP, Hamers T. Competitive binding of poly- and perfluorinated compounds to the thyroid hormone transport protein transthyretin. Toxicol Sci (2009) 109(2):206-16. doi:10.1093/toxsci/kfp055

71. Yu WG, Liu W, Jin YH. Effects of perfluorooctane sulfonate on rat thyroid hormone biosynthesis and metabolism. Environ Toxicol Chem (2009) 28(5): 990-6. doi:10.1897/08-345.1

72. Lopez-Espinosa MJ, Mondal D, Armstrong B, Bloom MS, Fletcher T. Thyroid function and perfluoroalkyl acids in children living near a chemical plant. Environ Health Perspect (2012) 120(7):1036-41. doi:10.1289/ehp.1104370

73. Shah-Kulkarni S, Kim BM, Hong YC, Kim HS, Kwon EJ, Park H, et al. Prenatal exposure to perfluorinated compounds affects thyroid hormone levels in newborn girls. Environ Int (2016) 94:607-13. doi:10.1016/j.envint. 2016.06.024

74. de Cock M, de Boer MR, Lamoree M, Legler J, van de Bor M. Prenatal exposure to endocrine disrupting chemicals in relation to thyroid hormone levels in infants - a Dutch prospective cohort study. Environ Health (2014) 13:106. doi:10.1186/1476-069X-13-106

75. Braun JM. Early-life exposure to EDCs: role in childhood obesity and neurodevelopment. Nat Rev Endocrinol (2017) 13(3):161-73. doi:10.1038/ nrendo.2016.186

76. Fei C, McLaughlin JK, Lipworth L, Olsen J. Prenatal exposure to perfluorooctanoate (PFOA) and perfluorooctanesulfonate (PFOS) and maternally reported developmental milestones in infancy. Environ Health Perspect (2008) 116(10):1391-5. doi:10.1289/ehp.11277

77. Fei C, Olsen J. Prenatal exposure to perfluorinated chemicals and behavioral or coordination problems at age 7 years. Environ Health Perspect (2011) 119(4):573-8. doi:10.1289/ehp.1002026

78. Liew Z, Ritz B, von Ehrenstein OS, Bech BH, Nohr EA, Fei C, et al. Attention deficit/hyperactivity disorder and childhood autism in association with prenatal exposure to perfluoroalkyl substances: a nested case-control study in the Danish National Birth Cohort. Environ Health Perspect (2015) 123(4):367-73. doi:10.1289/ehp.1408412

79. Oulhote Y, Steuerwald U, Debes F, Weihe P, Grandjean P. Behavioral difficulties in 7-year old children in relation to developmental exposure to perfluorinated alkyl substances. Environ Int (2016) 97:237-45. doi:10.1016/j. envint.2016.09.015

80. Chen MH, Ha EH, Liao HF, Jeng SF, Su YN, Wen TW, et al. Perfluorinated compound levels in cord blood and neurodevelopment at 2 years of age. Epidemiology (2013) 24(6):800-8. doi:10.1097/EDE.0b013e3182a6dd46
81. Hoyer BB, Ramlau-Hansen CH, Obel C, Pedersen HS, Hernik A, Ogniev V, et al. Pregnancy serum concentrations of perfluorinated alkyl substances and offspring behaviour and motor development at age 5-9 years - a prospective study. Environ Health (2015) 14:2. doi:10.1186/1476-069X-14-2

82. Lien GW, Huang CC, Shiu JS, Chen MH, Hsieh WS, Guo YL, et al. Perfluoroalkyl substances in cord blood and attention deficit/hyperactivity disorder symptoms in seven-year-old children. Chemosphere (2016) 156:118-27. doi:10.1016/j.chemosphere.2016.04.102

83. Vuong AM, Yolton K, Webster GM, Sjodin A, Calafat AM, Braun JM, et al. Prenatal polybrominated diphenyl ether and perfluoroalkyl substance exposures and executive function in school-age children. Environ Res (2016) 147:556-64. doi:10.1016/j.envres.2016.01.008

84. Quaak I, de Cock M, de Boer M, Lamoree M, Leonards P, van de Bor M. Prenatal exposure to perfluoroalkyl substances and behavioral development in children. Int J Environ Res Public Health (2016) 13(5):511. doi:10.3390/ ijerph13050511

85. Berg V, Nost TH, Pettersen RD, Hansen S, Veyhe AS, Jorde R, et al. Persistent organic pollutants and the association with maternal and infant thyroid homeostasis: a multipollutant assessment. Environ Health Perspect (2016) 125:127-33. doi:10.1289/EHP152

86. Lind DV, Priskorn L, Lassen TH, Nielsen F, Kyhl HB, Kristensen DM, et al. Prenatal exposure to perfluoroalkyl substances and anogenital distance at 3 months of age in a Danish mother-child cohort. Reprod Toxicol (2016). doi:10.1016/j.reprotox.2016.07.008

87. Leung AM, Pearce EN, Braverman LE. Environmental perchlorate exposure: potential adverse thyroid effects. Curr Opin Endocrinol Diabetes Obes (2014) 21(5):372-6. doi:10.1097/MED.0000000000000090

88. Blount BC, Pirkle JL, Osterloh JD, Valentin-Blasini L, Caldwell KL. Urinary perchlorate and thyroid hormone levels in adolescent and adult men and women living in the United States. Environ Health Perspect (2006) 114(12):1865-71. doi:10.1289/ehp.9466

89. Suh M, Abraham L, Hixon JG, Proctor DM. The effects of perchlorate, nitrate, and thiocyanate on free thyroxine for potentially sensitive subpopulations of the 2001-2002 and 2007-2008 National Health and Nutrition Examination Surveys. J Expo Sci Environ Epidemiol (2014) 24(6):579-87. doi:10.1038/ jes.2013.67

90. McMullen J, Ghassabian A, Kohn B, Trasande L. Identifying subpopulations vulnerable to the thyroid-blocking effects of perchlorate and thiocyanate. J Clin Endocrinol Metab (2017) 102(7):2637-45. doi:10.1210/jc.201700046

91. Taylor PN, Okosieme OE, Murphy R, Hales C, Chiusano E, Maina A, et al. Maternal perchlorate levels in women with borderline thyroid function during pregnancy and the cognitive development of their offspring: data from the Controlled Antenatal Thyroid Study. J Clin Endocrinol Metab (2014) 99(11):4291-8. doi:10.1210/jc.2014-1901

92. Calafat AM, Kuklenyik Z, Reidy JA, Caudill SP, Ekong J, Needham LL. Urinary concentrations of bisphenol A and 4-nonylphenol in a human reference population. Environ Health Perspect (2005) 113(4):391-5. doi:10.1289/ ehp. 7534

93. Lewis JB, Lapp CA, Schafer TE, Wataha JC, Randol TM, Schuster GS. 4-Hydroxytamoxifen-induced cytotoxicity and bisphenol A: competition for estrogen receptors in human breast cancer cell lines. In Vitro Cell Dev Biol Anim (2000) 36(5):320-6. doi:10.1290/1071-2690(2000)036<0320: $\mathrm{HICABA}>2.0 . \mathrm{CO} ; 2$

94. Moriyama K, Tagami T, Akamizu T, Usui T, Saijo M, Kanamoto N, et al. Thyroid hormone action is disrupted by bisphenol A as an antagonist. J Clin Endocrinol Metab (2002) 87(11):5185-90. doi:10.1210/jc.2002-020209

95. Zoeller RT, Bansal R, Parris C. Bisphenol-A, an environmental contaminant that acts as a thyroid hormone receptor antagonist in vitro, increases serum thyroxine, and alters RC3/neurogranin expression in the developing rat brain. Endocrinology (2005) 146(2):607-12. doi:10.1210/en.2004-1018

96. Nakamura K, Itoh K, Yaoi T, Fujiwara Y, Sugimoto T, Fushiki S. Murine neocortical histogenesis is perturbed by prenatal exposure to low doses of bisphenol A. J Neurosci Res (2006) 84(6):1197-205. doi:10.1002/jnr. 21020

97. Lee S, Kim C, Youn H, Choi K. Thyroid hormone disrupting potentials of bisphenol $\mathrm{A}$ and its analogues - in vitro comparison study employing rat pituitary (GH3) and thyroid follicular (FRTL-5) cells. Toxicol In Vitro (2017) 40:297-304. doi:10.1016/j.tiv.2017.02.004 
98. Helbing CC, van Aggelen G, Veldhoen N. Triclosan affects thyroid hormonedependent metamorphosis in anurans. Toxicol Sci (2011) 119(2):417-8; author reply 419-22. doi:10.1093/toxsci/kfq343

99. Meeker JD, Ferguson KK. Relationship between urinary phthalate and bisphenol A concentrations and serum thyroid measures in U.S. adults and adolescents from the National Health and Nutrition Examination Survey (NHANES) 2007-2008. Environ Health Perspect (2011) 119(10):1396-402. doi:10.1289/ehp.1103582

100. Sriphrapradang C, Chailurkit LO, Aekplakorn W, Ongphiphadhanakul B. Association between bisphenol A and abnormal free thyroxine level in men. Endocrine (2013) 44(2):441-7. doi:10.1007/s12020-013-9889-y

101. Wang N, Zhou Y, Fu C, Wang H, Huang P, Wang B, et al. Influence of bisphenol A on thyroid volume and structure independent of iodine in school children. PLoS One (2015) 10(10):e0141248. doi:10.1371/journal. pone. 0141248

102. Aung MT, Johns LE, Ferguson KK, Mukherjee B, McElrath TF, Meeker JD. Thyroid hormone parameters during pregnancy in relation to urinary bisphenol A concentrations: a repeated measures study. Environ Int (2017) 104:33-40. doi:10.1016/j.envint.2017.04.001

103. Chevrier J, Gunier RB, Bradman A, Holland NT, Calafat AM, Eskenazi B, et al. Maternal urinary bisphenol A during pregnancy and maternal and neonatal thyroid function in the CHAMACOS study. Environ Health Perspect (2013) 121(1):138-44. doi:10.1289/ehp.1205092

104. Romano ME, Webster GM, Vuong AM, Thomas Zoeller R, Chen A, Hoofnagle AN, et al. Gestational urinary bisphenol A and maternal and newborn thyroid hormone concentrations: the HOME Study. Environ Res (2015) 138:453-60. doi:10.1016/j.envres.2015.03.003

105. Braun JM, Yolton K, Dietrich KN, Hornung R, Ye X, Calafat AM, et al. Prenatal bisphenol A exposure and early childhood behavior. Environ Health Perspect (2009) 117(12):1945-52. doi:10.1289/ehp.0900979

106. Braun JM, Kalkbrenner AE, Calafat AM, Yolton K, Ye X, Dietrich KN, et al. Impact of early-life bisphenol A exposure on behavior and executive function in children. Pediatrics (2011) 128(5):873-82. doi:10.1542/peds. 2011-1335

107. Perera F, Vishnevetsky J, Herbstman JB, Calafat AM, Xiong W, Rauh V, et al. Prenatal bisphenol A exposure and child behavior in an innerity cohort. Environ Health Perspect (2012) 120(8):1190-4. doi:10.1289/ehp.1104492

108. Roen EL, Wang Y, Calafat AM, Wang S, Margolis A, Herbstman J, et al. Bisphenol A exposure and behavioral problems among inner city children at 7-9 years of age. Environ Res (2015) 142:739-45. doi:10.1016/j. envres.2015.01.014

109. Perera F, Nolte EL, Wang Y, Margolis AE, Calafat AM, Wang S, et al. Bisphenol A exposure and symptoms of anxiety and depression among inner city children at 10-12 years of age. Environ Res (2016) 151:195-202. doi:10.1016/j.envres.2016.07.028

110. Braun JM, Muckle G, Arbuckle T, Bouchard MF, Fraser WD, Ouellet E, et al. Associations of prenatal urinary bisphenol A concentrations with child behaviors and cognitive abilities. Environ Health Perspect (2017) 125(6):067008. doi:10.1289/EHP984

111. Silva MJ, Barr DB, Reidy JA, Malek NA, Hodge CC, Caudill SP, et al. Urinary levels of seven phthalate metabolites in the U.S. population from the National Health and Nutrition Examination Survey (NHANES) 1999-2000. Environ Health Perspect (2004) 112(3):331-8. doi:10.1289/ehp.6723

112. Hendryx M, Luo J. Children's environmental chemical exposures in the USA, NHANES 2003-2012. Environ Sci Pollut Res Int (2018) 25(6):5336-43. doi:10.1007/s11356-017-0874-5

113. Morgenstern R, Whyatt RM, Insel BJ, Calafat AM, Liu X, Rauh VA, et al. Phthalates and thyroid function in preschool age children: sex specific associations. Environ Int (2017) 106:11-8. doi:10.1016/j.envint.2017.05.007

114. Park C, Choi W, Hwang M, Lee Y, Kim S, Yu S, et al. Associations between urinary phthalate metabolites and bisphenol A levels, and serum thyroid hormones among the Korean adult population - Korean National Environmental Health Survey (KoNEHS) 2012-2014. Sci Total Environ (2017) 58(4-585):950-7. doi:10.1016/j.scitotenv.2017.01.144

115. Weng TI, Chen MH, Lien GW, Chen PS, Lin JC, Fang CC, et al. Effects of gender on the association of urinary phthalate metabolites with thyroid hormones in children: a prospective Cohort Study in Taiwan. Int J Environ Res Public Health (2017) 14(2):E123. doi:10.3390/ijerph14020123

116. Huang HB, Chuang CJ, Su PH, Sun CW, Wang CJ, Wu MT, et al. Prenatal and childhood exposure to phthalate diesters and thyroid function in a 9-year follow-up birth cohort study: Taiwan Maternal and Infant Cohort Study. Epidemiology (2017)28(Suppl 1):S10-8. doi:10.1097/EDE.0000000000000722

117. Kuo FC, Su SW, Wu CF, Huang MC, Shiea J, Chen BH, et al. Relationship of urinary phthalate metabolites with serum thyroid hormones in pregnant women and their newborns: a prospective birth cohort in Taiwan. PLoS One (2015) 10(6):e0123884. doi:10.1371/journal.pone.0123884

118. Johns LE, Ferguson KK, McElrath TF, Mukherjee B, Meeker JD. Associations between repeated measures of maternal urinary phthalate metabolites and thyroid hormone parameters during pregnancy. Environ Health Perspect (2016) 124(11):1808-15. doi:10.1289/EHP170

119. Minatoya M, Naka Jima S, Sasaki S, Araki A, Miyashita C, Ikeno T, et al. Effects of prenatal phthalate exposure on thyroid hormone levels, mental and psychomotor development of infants: the Hokkaido Study on Environment and Children's Health. Sci Total Environ (2016) 565:1037-43. doi:10.1016/j. scitotenv.2016.05.098

120. Sun D, Zhou L, Wang S, Liu T, Zhu J, Jia Y, et al. Effect of Di-(2-ethylhexyl) phthalate on the hypothalamus-pituitary-thyroid axis in adolescent rat. Endocr J (2018) 65(3):261-8. doi:10.1507/endocrj.EJ17-0272

121. Zhai W, Huang Z, Chen L, Feng C, Li B, Li T. Thyroid endocrine disruption in zebrafish larvae after exposure to mono-(2-ethylhexyl) phthalate (MEHP). PLoS One (2014) 9(3):e92465. doi:10.1371/journal.pone.0092465

122. Factor-Litvak P, Insel B, Calafat AM, Liu X, Perera F, Rauh VA, et al. Persistent associations between maternal prenatal exposure to phthalates on child IQ at age 7 years. PLoS One (2014) 9(12):e114003. doi:10.1371/journal.pone. 0114003

123. Lien YJ, Ku HY, Su PH, Chen SJ, Chen HY, Liao PC, et al. Prenatal exposure to phthalate esters and behavioral syndromes in children at 8 years of age: Taiwan Maternal and Infant Cohort Study. Environ Health Perspect (2015) 123(1):95-100. doi:10.1289/ehp.1307154

124. Philippat C, Bennett DH, Krakowiak P, Rose M, Hwang H-M, Hertz-Picciotto I. Phthalate concentrations in house dust in relation to autism spectrum disorder and developmental delay in the CHildhood Autism Risks from Genetics and the Environment (CHARGE) study. Environ Health (2015) 14:56. doi:10.1186/s12940-015-0024-9

125. Ipapo KN, Factor-Litvak P, Whyatt RM, Calafat AM, Diaz D, Perera F, et al. Maternal prenatal urinary phthalate metabolite concentrations and visual recognition memory among infants at 27 weeks. Environ Res (2017) 155(Suppl C):7-14. doi:10.1016/j.envres.2017.01.019

126. Schmidt CW. Growing a new study: environmental influences on child health outcomes. Environ Health Perspect. (2015) 123(10):A260-3. doi:10.1289/ ehp. $123-\mathrm{A} 260$

127. Benvenga S, Vigo MT, Metro D, Granese R, Vita R, Le Donne M. Type of fish consumed and thyroid autoimmunity in pregnancy and postpartum. Endocrine (2016) 52(1):120-9. doi:10.1007/s12020-015-0698-3

128. Le Donne M, Alibrandi A, Vita R, Zanghi D, Triolo O, Benvenga S. Does eating oily fish improve gestational and neonatal outcomes? Findings from a Sicilian study. Women Birth (2016) 29(3):e50-7. doi:10.1016/j.wombi.2015. 12.005

Conflict of Interest Statement: The authors declare that the research was conducted in the absence of any commercial or financial relationships that could be construed as a potential conflict of interest.

The handling Editor and reviewer BD declared their involvement as co-editors in the Research Topic, and confirm the absence of any other collaboration.

Copyright $\odot 2018$ Ghassabian and Trasande. This is an open-access article distributed under the terms of the Creative Commons Attribution License (CC BY). The use, distribution or reproduction in other forums is permitted, provided the original author(s) and the copyright owner are credited and that the original publication in this journal is cited, in accordance with accepted academic practice. No use, distribution or reproduction is permitted which does not comply with these terms. 